\title{
First record of Ceratium furcoides (Dinophyta), an invasive species, in a temporary high-altitude lake in the Iron Quadrangle (MG, Southeast Brazil)
}

\author{
Moreira, RA. ${ }^{a *}$, Rocha, O. ${ }^{a}$, Santos, RM. ${ }^{a}$, Laudares-Silva, R. ${ }^{b}$, \\ Dias, ES.' ${ }^{c}$ and Eskinazi-Sant'Anna, EM. ${ }^{c}$ \\ aPrograma de Pós-Graduação em Ecologia e Recursos Naturais, Universidade Federal de São Carlos - UFSCar, \\ Rodovia Washington Luiz, Km 235, s/n, Bairro Monjolinho, CP 676, CEP 13565-905, São Carlos, SP, Brazil \\ ${ }^{\text {b}}$ Departamento de Botânica, Universidade Federal de Santa Catarina - UFSC, Campus Universitário, s/n, \\ Trindade, CP 476, CEP 88040-900, Florianópolis, SC, Brazil
}

'Laboratório de Ecologia Aquática, Departamento de Biodiversidade, Evolução e Meio Ambiente, Universidade Federal de Ouro Preto - UFOP, Campus Morro do Cruzeiro, s/n, Bauxita, CEP 35400-000, Ouro Preto, MG, Brazil *e-mail: raquel.moreira87@yahoo.com.br

Received: May 22, 2013 - Accepted: October 7, 2013 - Distributed: March 31, 2015

(With 3 figures)

\begin{abstract}
Dinoflagellates of the genus Ceratium are generally marine organisms, but rare occurrences in freshwater have been observed in Brazil. In this paper we are recording for the first time the presence of Ceratium furcoides, an invasive species, in a shallow, natural intermittent pool formed at a high-altitude at the southern end of the Iron Quadrangle, an iron-mining district of Minas Gerais State (Southeast Brazil). Samples were collected in October and November of 2010 (rainy period). The population density of this organism observed in Lagoa Seca ("Dry Pool") was very low, at most 4 ind $\mathrm{L}^{-1}$. Mountain lakes are extremely vulnerable to atmospheric deposition of organisms, making them valuable witnesses both of the many forms of impact arising from human activities and of the extended global connections that facilitate the dispersion and introduction of new species over great distances. Studies on the population dynamics of C. furcoides in natural tropical systems are still rare and very recent to the brazilian scenario and hence the monitoring of its dynamics and the potential impact on aquatic communities of its becoming established are essential to an understanding of the process of bioinvasion by this species.
\end{abstract}

Keywords: bioinvasion, dinoflagellate, Ceratium furcoides, high-altitude lake, Minas Gerais.

\section{Primeiro registro de Ceratium furcoides (Dinophyta), uma espécie invasora, em um lago temporário de alta altitude no Quadrilátero Ferrífero (MG, Sudeste do Brasil)}

\section{Resumo}

Dinoflagelados do gênero Ceratium são principalmente marinhos, porém existem raras ocorrências em água doce no Brasil. Neste estudo registramos pela primeira vez a ocorrência de Ceratium furcoides, uma espécie invasora em um lago altitudinal natural raso localizado na porção sul do Quadrilátero Ferrífero, uma área de extração mineral no estado de Minas Gerais. As coletas foram realizadas nos meses de outubro e novembro de 2010 (período chuvoso). As densidades observadas para C. furcoides na Lagoa Seca foram muito baixas, com máximo de 4 ind L $\mathrm{L}^{-1}$. Lagos de altitude são altamente vulneráveis à deposição atmosférica, o que os torna importantes testemunhos não só dos múltiplos impactos derivados de atividades humanas, mas também das extensas conexões globais, que acabam por facilitar a dispersão e introdução de espécies. Estudos sobre a dinâmica de C. furcoides em sistemas tropicais naturais ainda são escassos e por isso, o monitoramento de sua dinâmica e dos impactos potenciais em comunidades aquáticas a partir do seu estabelecimento, torna-se fundamental para o entendimento dos processos relacionados à bioinvasão desta espécie.

Palavras-chave: bioinvasão, dinoflagelado, Ceratium furcoides, lago de alta altitude, Minas Gerais. 


\section{Introduction}

Around the world, natural communities and ecosystems are increasingly disturbed by the invasion of non-native species. Very few communities and ecosystems in the world have remained unaffected by exotic species (Heywood, 1989; Dzialowski et al., 2000). The majority of introduced species have little or no effect on native communities (Simberloff, 1996; Lodge, 1993; Williamson, 1996). However, some have a dramatic impact, causing deep changes in the structure of habitats, trophic interactions and population dynamics (Crooks, 2005). Furthermore, the species introduced tend to increase the similarity among the biota of different regions, a tendency widely observed on various geographic scales and affecting many kinds of organism (Vitousek et al., 1996; Lockwood and McKinney, 2001). If an introduced species becomes abundant in a new environment, evidencing its highly adaptive capacity, it may turn out to be invasive and lead to severe consequences for the ecosystem, the most prejudicial being the extinction of native species, caused mainly, by strong competition or predation (Baskin, 1994).

Natural ecosystems are particularly vulnerable to biological invasions, owing to many factors, including high degree of connectivity, strong spatial influence (horizontal and vertical), anthropogenic impact and high habitat heterogeneity, that increase the chance of species establishment (Simberloff, 1996). Dinoflagellates of Ceratium genus can be found in both marine and freshwater habitats. Bicudo and Menezes (2005) reported the occurrence of six species of this genus in continental water bodies around the world, found mainly in temperate areas $(\mathrm{Wu}$ and Chou 1998). These dinoflagellates have been already recorded in freshwaters from various regions of the world, including for Europe: Hungary (Padisák, 1985), Spain (Pérez-Martínez and Sánchez-Castillo, 2001), Greece (Katsiapi et al., 2011), Britain (Lewis and Dodge, 2002; Whitton et al., 2003), Romania (Caraus, 2002) and Italy (Hansen and Flaim, 2007); in Asia: Taiwan (Wu and Chou, 1998), Japan (Carty, 2003) and India (Bhat et al., 2012); in Oceania: Australia (Whittington et al., 2000; Baldwin et al., 2003); in American continent: USA, Canada and Argentina (Mac Donagh et al., 2005, 2009) and in Africa: South Africa (Der Walt, 2011) and many shallow lakes (Ndebele-Murisa et al., 2010).

The first register of $C$. hirundinella in Brazilian freshwaters was made by Branco et al. (1963). Since then several records of the occurrence of this dinoflagellate in many Brazilian aquatic ecosystems were published (SantosWisniewski et al., 2007; Matsumura-Tundisi et al., 2010; Oliveira et al., 2011; Severiano et al., 2012; Silva et al., 2012. To our knowledge, this is the first time that the occurrence of Ceratium furcoides is reported in a highaltitude natural, shallow, temporary lake in Brazil.

\section{Material and Methods}

Plankton samples were collected in the months of October and November 2010 from a small temporary lake, named Lagoa Seca (Figure 1). Lagoa Seca is located in a small depression at 1,609 $\mathrm{m}$ above sea level, in Itacolomi State Park (PEIT), a Conservation Unit located between the towns of Ouro Preto and Mariana, in the southern portion of the Iron Quadrangle in Minas Gerais State $\left(20^{\circ} 22^{\prime} 30^{\prime \prime}-20^{\circ} 30^{\prime} 00^{\prime}\right.$ " $\mathrm{S}$ by $43^{\circ} 32^{\prime} 30^{\prime \prime}-43^{\circ} 22^{\prime} 30^{\prime \prime}$ $\mathrm{W})$. The lake is formed by water springs and reaches a maximum depth of $1.5 \mathrm{~m}$ in the rainy season, drying out completely in the period between April and September, the local dry season.

Zooplankton samples were taken by filtering $90 \mathrm{~L}$ of water through a plankton net of $30 \mathrm{~cm}$ mouth diameter aperture and $68 \mu \mathrm{m}$ mesh aperture. Samples were preserved in $4 \%$ formaldehyde solution. Ceratium furcoides was identified and its abundance was determined by counting subsamples in the Sedgwick-Rafter chamber under an optical microscope at 100 times magnification.

Ceratium furcoides cells were observed and photographed under an Olympus BX50 microscope (Figure 2). Cells were clarified with $20 \% \mathrm{NaClO}$ solution for plate tabulation analysis. The taxonomical analysis was based on Popovský and Pfiester (1990) and Steidinger and Tanger (1997) descriptions.

\section{Results and Discussion}

The individuals found in the samples measured $180-209 \mu \mathrm{m}$ in total length and 51-60 $\mu \mathrm{m}$ in maximum width (Figure 2). C. furcoides is very similar to Ceratium hirundinella, the main distinctions being the difference in the apical plate tabulation: in C. hirundinella, 4 apical plates reach the apex, whereas in C. furcoides, which also has 4 apical plates, only 3 of them reach the apex (according description by Santos-Wisniewski et al., 2007).

These two species are spreading fast in many areas and it is important to be able to distinguish them readily to allow an accurate follow-up of their invasion route and speed. To facilitate the differentiation of these two species, their main diagnostic characteristics were presented in Figure 3 and described as follows:

Description

1. Ceratium furcoides (Levander) Langhans 1925 (Figures $3 \mathrm{a}$ and $3 \mathrm{~b}$ )

Cells are narrowly fusiform in outline and strongly flattened dorsi-ventrally. The epivalve is narrowly conical; a long horn forms from just above the cingulum. The cingulum is slightly narrow. The body of the hypovalve is broad and short. It is formed by the antapical plates. On the epivalve of this species there are four apical plates, one of which, the 4' does not reach the apex.

Dimensions: 123-322 $\mu \mathrm{m}$ X 28-42 (56) $\mu \mathrm{m}$.

Occurrence: According to the literature it occurs from oligotrophic to eutrophic lakes and reservoirs; It has been recorded in North and South America, Europe, Asia, Africa and Oceania.

2. Ceratium hirundinella (O. F. Müller) Dujardin 1841 (Figures 3c and 3d)

Cells are broadly or narrowly fusiform in outline, depending upon the degree of divergence of the horns. 


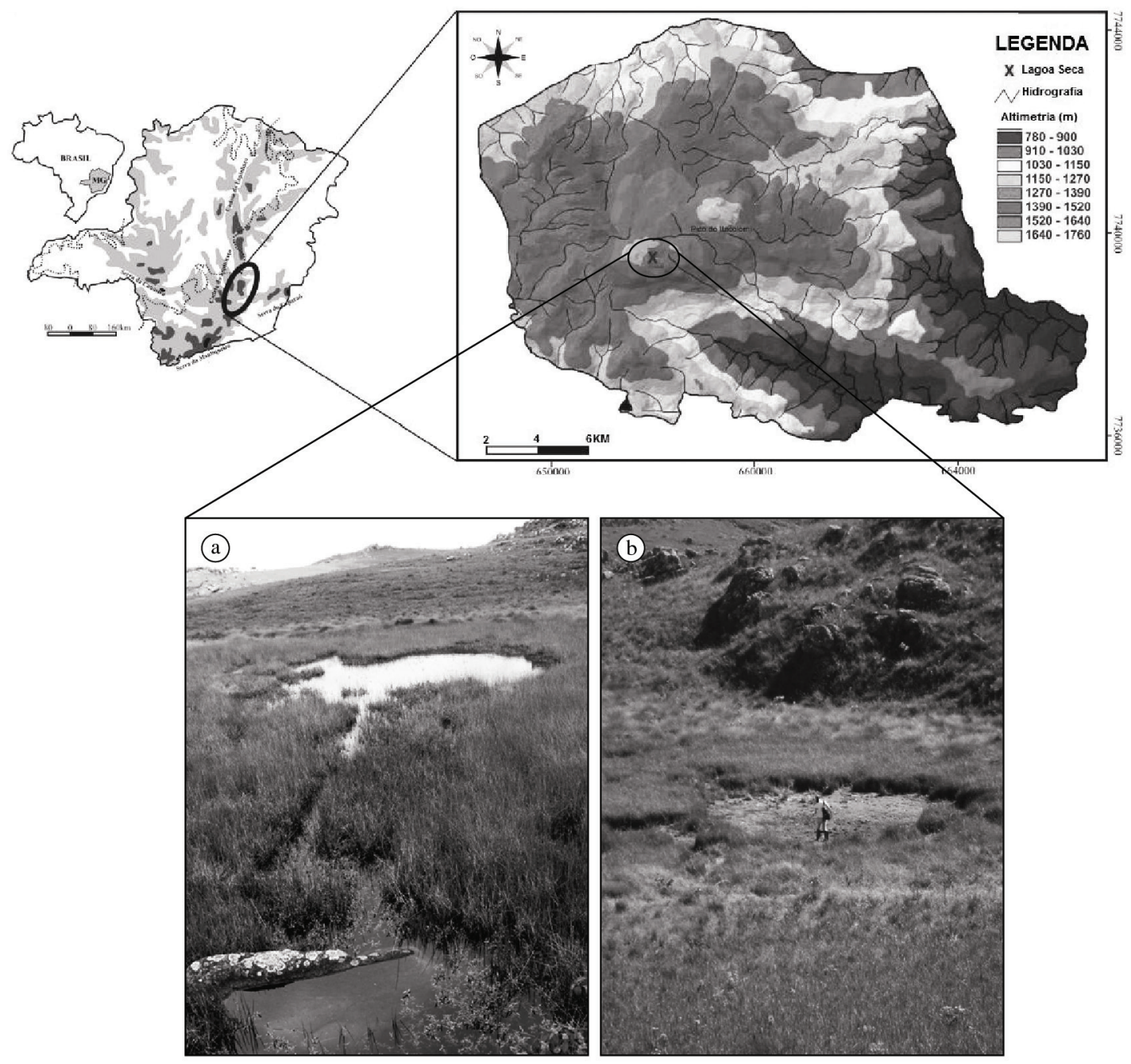

Figure 1. Map showing the location of Lagoa Seca in Brazil, Minas Gerais State and the State Itacolomi Park (MG, Southeast Brazil): photographic views a) during the rainy season, when samples were collected; b) in the dry period, when the lake dried out.

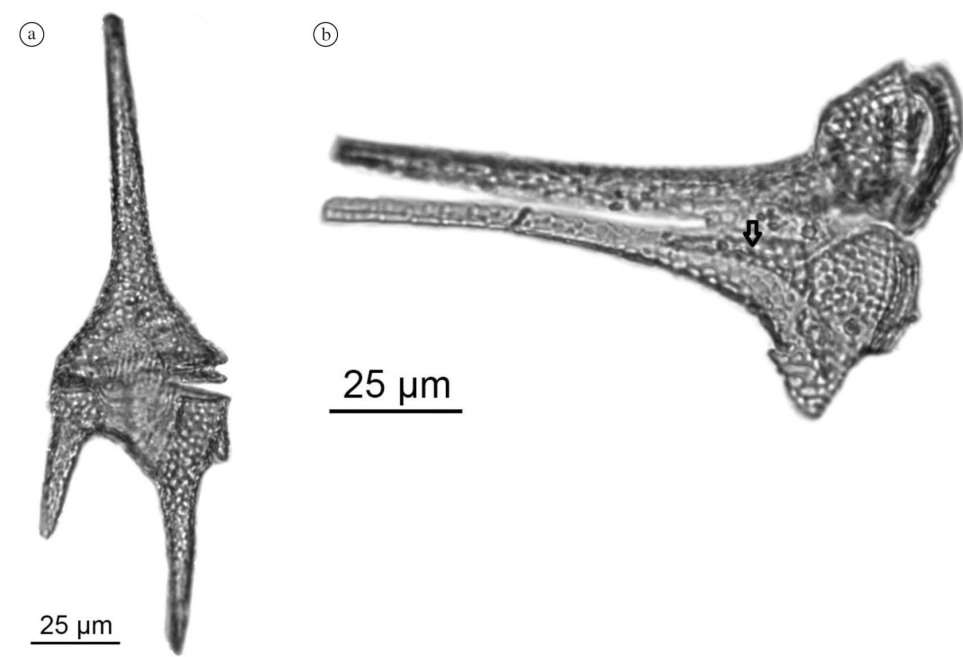

Figure 2. Ceratium furcoides: a) Dorsal view; b) Ventral view (treated with $\mathrm{NaClO}$ ). Plate 4' indicated by arrow. 

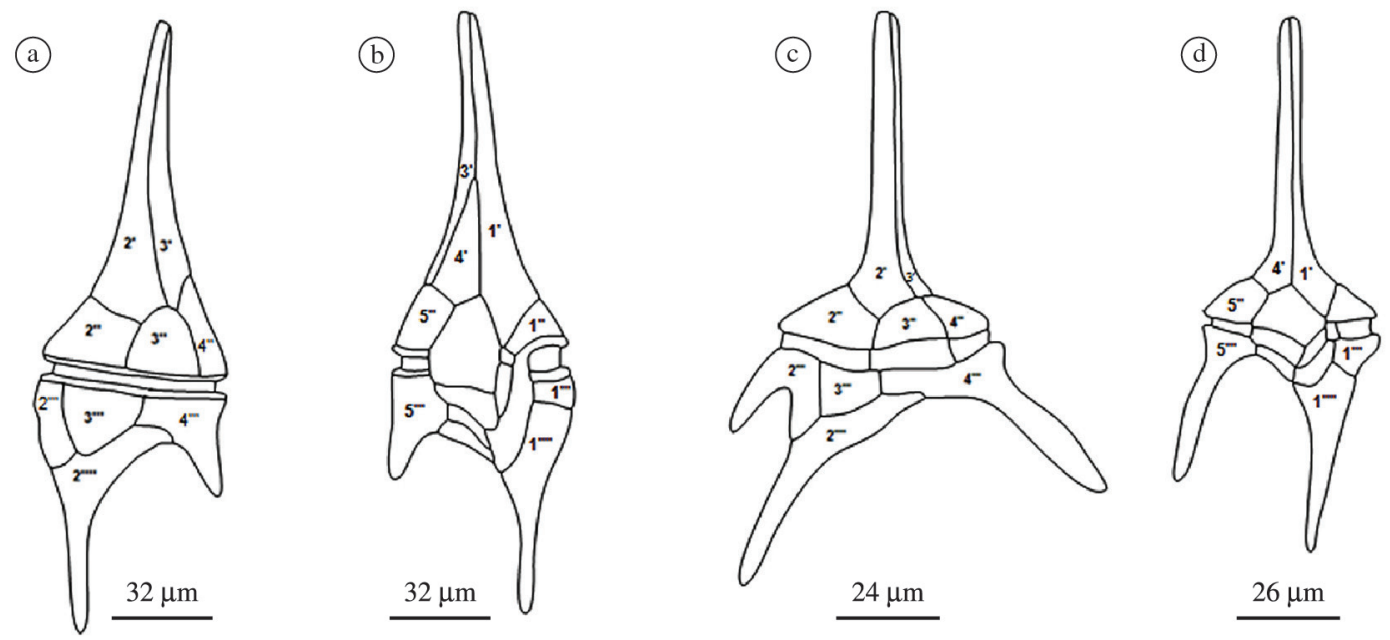

Figure 3. Drawing of distribution of plates on (a) dorsal and (b) ventral surface of Cearatium furcoides and (c) dorsal and (d) ventral surface of Ceratium hirundinella. C. furcoides drawings modified from Matsumura-Tundisi et al., (2010) and C. hirundinella drawings modified from Bourrelly (1970).

They are strongly flattened dorsiventrally. The helmetshaped epivalve narrows from just above the cingulum gradually forming a long horn with 4 apical plates. The cingulum is slightly narrow. The body of the hypovalve is broad and short. It is divided into a varying number of posterior horns, usually 3 , sometimes only 1 . The central or median horn formed by the antapical plates is the longest. Plates are coarsely reticulate with fine spicules.

Dimensions: 40 - $450 \mu \mathrm{m}$ X 28 - $55 \mu \mathrm{m}$,

Occurrence: Europe, North America, South America, Asia, Africa and Oceania.

Densities of $C$. furcoides in Lagoa Seca were very low, with a maximum of 4 ind $\mathrm{L}^{-1}$ in the limnetic region in October. On this sampling day, only 2 ind $\mathrm{L}^{-1}$ were recorded in the littoral region sample. Population densities in the November samples were 0.40 and 0.13 ind $\mathrm{L}^{-1}$ for the limnetic and littoral regions, respectively. These values are very low compared to densities recorded in natural lakes and reservoirs in the South American continent. In the eutrophic La Quebrada Lake in Argentina, C. hirundinella densities surpassed 30,000 ind L ${ }^{-1}$ (Periotto et al., 2007). In Southeastern Brazil, Matsumura-Tundisi et al. (2010) reported high densities of Ceratium furcoides in the eutrophic Billings reservoir $\left(25,000\right.$ ind $\left.\mathrm{L}^{-1}\right)$, while Silva et al. (2012) recorded a maximum density of 28,564 ind $\mathrm{L}^{-1}$ in the mesotrophic Furnas Reservoir in Minas Gerais State.

The low density of $C$. furcoides in Lagoa Seca may also be related to the disturbances caused by the great water-level changes and drying up of this temporary pool. Lopez et al. (2012), highlights the influence of hydraulic dynamics as one of the primary factors determining the structural and temporal changes in phytoplankton communities in tropical high-mountain reservoirs, regardless of the nutrient concentration. Lagoa Seca is an oligotrophic ecosystem (Eskinazi-Sant'Anna et al., 2011), and the reservoirs where high densities of $C$. furcoides were found are all mesotrophic, eutrophic or hypereutrophic (Wu and Chou, 1998; Matsumura-Tundisi et al., 2010; Bustamante-Gil et al., 2012). According to Andrade et al. (2012), the soils of the Itacolomi State Park are extremely rich in organic matter, but with low availability of nutrients. The availability of $P$ in the soil can be considered low to moderate $(1.2 \mathrm{a} 4.1 \mathrm{mg}$ $\mathrm{dm}^{-3}$ ), probably related to high soil acidity (Terror et al., 2011). The high altitude of the area and its low temperatures, associated with the low soil $\mathrm{pH}$ contribute to the slow process of decomposition of organic matter, favoring the production of humic substances, which can sustain primary productivity in oligotrophic aquatic ecosystems (Daniel et al., 2005). All these conditions can explain the occurrence of the mixotrophic C. furcoides in Lagoa Seca.

The occurrence of $C$. furcoides in a temporary lake at high-altitude $(>1500 \mathrm{~m})$ draws attention to the invasive potential of exotic species and the vulnerability of unique mountain aquatic biota to biological invasions. Cyst-forming freshwater dinoflagellates seem to be geographically widespread and some species are found on several continents. One reason given for this wide geographic distribution is their ready dispersion via such anabiotic reproduction structures (Mertens et al., 2012).

Resting cysts are more resistant to harsh conditions such as drought and temperature change than the flagellated cells. Passive dispersal of cysts allows species to colonize new habitats and to extend their ranges. Moreover, along the shorelines of lakes, fragments of scum and foam, with their contents of algae, can be picked up by the wind and carried aloft. Algae can also be transported into the air by thermal winds, often after heavy rainfall, when algae have been splashed up by raindrops (Kristiansen, 1996). Thus, the concentrations of algae in the air are very dependent on meteorological conditions, including strong winds and rain, both of which are very common in the mountain region of the Iron Quadrangle. Mountain 
lakes are therefore highly vulnerable to aerial deposition of particles and drops and what they carry, making them important historical records not only of the extent of the impact of human activities, but also that of the broad global connections that facilitate the dispersion and introduction of species (Camarero et al., 2009).

Further information regarding the colonization of and full $C$. furcoides establishment in pristine tropical water bodies are not available and would be valuable for a better understanding of the dynamics of the invasion process as a whole.

\section{Acknowledgements}

To the Federal University of Ouro Preto (UFOP) for infrastructure facilities and FAPEMIG for financial support of the project (CRA - APQ-01767-11).

\section{References}

ANDRADE, LN., LEITE, MGP. and BACELLAR, LAP., 2012. Composição mineralógica e geoquímica dos solos do parque estadual do Itacolomi - Ouro Preto/MG. Quaternary and Environmental Geosciences, vol. 3, no. 1-2, p. 1-8.

BALDWIN, DS., WHITTINGTON, J. and OLIVER, R., 2003. Temporal variability of dissolved $\mathrm{P}$ speciation in a eutrophic reservoir: implications for predicating algal growth. Water Research, vol. 37, no. 19, p. 4595-4598. http://dx.doi.org/10.1016/ S0043-1354(03)00403-2. PMid:14568044

BASKIN, Y., 1994. Ecosystem function of biodiversity. BioScience, vol. 44, no. 10, p. 657-660. http://dx.doi.org/10.2307/1312507.

BHAT, NA., WANGANEO, A., RAINA, R., DAR, JA. and NAIK, AA., 2012. Phytoplankton diversity in relation to physicochemical characteristics of upper basin (Bhoj Wetland), Bhopal, India. Current Biotica, vol. 6, no. 3, p. 320-333.

BICUDO, CEM. and MENEZES, M. (Eds.). 2005. Gêneros de algas de águas continentais do Brasil. São Carlos: RIMA. 508 p.

BOURRELLY, P., 1970. Les algues d'eau douce: initiation à la systématique. Tome I: les algues vertes. Paris: Boubée \& Cie.

BRANCO, SM., BRANCO, WC., LIMA, HAS. and MARTINS, MT., 1963. Identificação e importância dos principais gêneros de algas de interesse para o tratamento de águas e esgoto. Revista do Departamento de Águas e Esgotos, vol. 48-50, p. 1-59.

BUSTAMANTE-GIL, C., RESTREPO, JJR., BOLTOVSKOY, A. and VALLEJO, A., 2012. Spatial and temporal change characterization of Ceratium furcoides (Dinophyta) in the equatorial reservoir Riogrande II, Colombia. Acta Limnologica Brasiliensia, vol. 24, no. 2, p. 207-219. http://dx.doi.org/10.1590/ S2179-975X2012005000039.

CAMARERO, L., BOTEV, L., MURI, G., PSENNER, R., ROSE, N. and STUCHLIK, E., 2009. Trace elements in alpine and artic lake sediments as a record of diffuse atmospheric contamination across Europe. Freshwater Biology, vol. 54, no. 12, p. 2518-2532. http://dx.doi.org/10.1111/j.1365-2427.2009.02303.x.

CARAUS, I., 2002. The algae of Romania. Studii si Cercetari, Universitatea Bacau. Biologie, vol. 7, p. 1-694.
CARTY, S., 2003. Dinoflagellates. In WEHRAND, JD. and SHEATH, RG. (Eds.). Freshwater Algae of North America. San Diego: Elsevier Science. p. 685-714. http://dx.doi.org/10.1016/ B978-012741550-5/50021-0.

CROOKS, JA., 2005. Lag times and exotic species: the ecology and management of biological invasions in slow-motion. Ecoscience, vol. 12, no. 3, p. 316-329. http://dx.doi.org/10.2980/ i1195-6860-12-3-316.1.

DANIEL, C., GUTSEIT, K., ANESIO, AM. and GRANÉLI, M., 2005. Microbial food webs in the dark: independence of Lake Plankton from recent algal production. Aquatic Microbial Ecology, vol. 38, p. 113-123. http://dx.doi.org/10.3354/ame038113.

DER WALT, VN., 2011. Investigation into the occurrence of the dinoflagellate, Ceratium hirundinella in source waters and the impact thereof on drinking water purification. Potchefstroom: North-West University. Master's thesis in Environmental Sciences.

DZIALOWSKI, A., O'BRIEN, WJ. and SWAFFAR, SM., 2000. Range expansion and potential dispersal mechanisms of the exotic cladoceran Daphnia lumholtzi. Journal of Plankton Research, vol. 22, no. 12, p. 2205-2223. http://dx.doi.org/10.1093/ plankt/22.12.2205

ESKINAZI-SANT'ANNA, EM., FREITAS, LD. and MOREIRA, RA., 2011. Ecossistemas lacustres montanos: biodiversidade e grau de vulnerabilidade à ação antrópica. $M G$-Biota, vol. 4, no. 1, p. $37-40$.

HANSEN, G. and FLAIM, G., 2007. Dinoflagellates of the Trentino Province, Italy. Journal of Limnology, vol. 66, no. 2, p. 107-141. http://dx.doi.org/10.4081/jlimnol.2007.107.

HEYWOOD, VH., 1989. Patterns, extents and modes of invasion by terrestrial plants. In DRAKE, JA., MOONEY, HA., DI CASTRI, F., GROVES, RH., KRUGER, FJ., REJMÁNEK, M. and WILLIAMSON, M. (Eds.). Biological invasions: a global perspective.. New York: John Wiley and Sons. p. 31-61. Scope 37.

KATSIAPI, M., MOUSTAKA-GOUNI, M., MICHALOUDI, E. and KORMAS, KA., 2011. Phytoplankton and water quality in a Mediterranean drinking-water reservoir (Marathonas Reservoir, Greece). Environmental Monitoring and Assessment, vol. 181, no. 1-4, p. 563-575. http://dx.doi.org/10.1007/s10661-010-18513. PMid: 21213042

KRISTIANSEN, J., 1996. Dispersal of freshwater algae: a review. Hydrobiologia, vol. 336, no. 1-3, p. 151-157. http://dx.doi. org/10.1007/BF00010829.

LEWIS, JM. and DODGE, JD., 2002. Phylum Pyrrophyta (Dinoflagellates). In JOHN, DM., WHITTON, BA. and BROOK, AJ. (Eds.). The freshwater algal flora of the british isles: an identification guide to freshwater and terrestrial algae. Cambridge: Cambridge University Press. p. 186-207.

LOCKWOOD, JL. and MCKINNEY, ML., 2001. Biotic homogenization. Springer. 289 p.. http://dx.doi.org/10.1007/9781-4615-1261-5.

LODGE, DM., 1993. Species invasions and deletions: communities effects and responses to climate and habitat change. In KAREIVA, PM., KINGSOLVER, JG. and HUEY, RB. (Eds.). Biotic interactions and global change. Massachussets: Sinauer Associates Inc. p. 367-387.

LÓPEZ, N.L., RONDÓN, C.A.R., ZAPATA, A., JIMÉNEZ, J., VILLAMIL, W., ARENAS, G., RINCÓN, C. and SÁNCHEZ, T., 2012. Factors controlling phytoplankton in tropical high-mountain drinking-water reservoirs. Limnética, vol. 31, no. 2, p. 305-322. 
MAC DONAGH, ME., CASCO, MA. and CLAPS, MC., 2005. Colonization of a neotropical reservoir (Córdoba, Argentina) by Ceratium hirundinella (O. F. Müller). Annales de Limnologie: Journal of Limnology, vol. 41, no. 4, p. 291-299. http://dx.doi. org/10.1051/limn/2005020.

MAC DONAGH, ME., CASCO, MA. and CLAPS, MC., 2009. Plankton relationships under small water level fluctuations in a subtropical reservoir. Aquatic Ecology, vol. 43, no. 2, p. 371-381. http://dx.doi.org/10.1007/s10452-008-9197-4.

MATSUMURA-TUNDISI, T., TUNDISI, JG., LUZIA, AP. and DEGANI, RM., 2010. Occurrence of Ceratium furcoides (Levander) Langhans 1925 bloom at the Billings Reservoir, São Paulo State, Brazil. Brazilian Journal of Biology $=$ Revista Brasileira de Biologia, vol. 70, no. 3, supplement, p. 825-829. http://dx.doi. org/10.1590/S1519-69842010000400013. PMid:21085787

MERTENS, KN., RENGEFORS, K., MOESTRUP, Ø. and ELLEGAARD, M., 2012. A review of recent freshwater dinoflagellate cysts: taxonomy, phylogeny, ecology and palaeocology. Phycologia, vol. 51, no. 6, p. 612-619. http://dx.doi.org/10.2216/11-89.1.

NDEBELE-MURISA, MR., MUSIL, CF. and RAITT, L., 2010. A review of phytoplankton dynamics in tropical African lakes. South African Journal of Science, vol. 106, no. 1-2, p. 13-18

OLIVEIRA, HSB., MOURA, NA. and CORDEIRO-ARAÚJO, MK., 2011. First record of Ceratium Schrank, 1973 (Dinophyceae: Ceratiaceae) in freshwater ecosystems in the semiarid region of Brazil. Check List, vol. 7, no. 5, p. 626-628.

PADISÁK, J., 1985. Population dynamics of the freshwater dinoflagellate Ceratium hirundinella in the largest shallow Lake of Central Europe, Lake Balaton, Hungary. Freshwater Biology, vol. 15, no. 1, p. 43-52. http://dx.doi.org/10.1111/j.1365-2427.1985. tb00695.x.

PÉREZ-MARTÍNEZ, C. and SÁNCHEZ-CASTILLO, P., 2001. Temporal occurrence of Ceratium hirundinella in Spanish reservoirs. Hydrobiologia, vol. 452, no. 1/3, p. 101-107. http:// dx.doi.org/10.1023/A:1011928027819.

PERIOTTO, M., PRÓSPERI, C., DAGA, C. and RINCÓN, A., 2007. Estudio de Ceratium hirundinella en El Embalse La Quebrada, Córdoba, Argentina. In International Congress on Development Environment and Natural Resources: Multi-level and Multi-scale Sustainability, 2007, Cochabamba, Bolívia.

POPOVSKÝ, J. and PFIESTER, LA., 1990. Dinophyceae. In ETTL, H., GERLOFF, J., HEYNIG, H. and MOLLEHAUER, D. (Eds.). Süsswasserflora von Mitteleuropa. Part 6. Jena: Gustav Fischer.
SANTOS-WISNIEWSKI, MJ., SILVA, LC., LEONE, IC., LAUDARES-SILVA, R. and ROCHA, O., 2007. First record of the occurrence of Ceratium furcoides (Levander) Langhans 1925, an invasive species in the hydroelectricity power plant Furnas Reservoir, MG, Brazil. Brazilian Journal of Biology = Revista Brasileira de Biologia, vol. 67, no. 4, p. 791-793. http:// dx.doi.org/10.1590/S1519-69842007000400033. PMid:18278340

SEVERIANO, JS., MOURA, AN., OLIVEIRA, HSB., CORDEIROARAÚJO, MK. and DANTAS, ÊW., 2012. Micro-phytoplankton richness in Contas River, state of Bahia, northeastern Brazil. Check List, vol. 8, no. 2, p. 218-223.

SILVA, LCD., LEONE, IC., SANTOS-WISNIEWSKI, MJ., PERET, AC. and ROCHA, O., 2012. Invasion of the dinoflagellate Ceratium furcoides (Levander) Langhans 1925 at tropical reservoir and its relation to environmental variables. Biota Neotropica, vol. 12, no. 2, p. 93-100. http://dx.doi.org/10.1590/S1676-06032012000200010.

SIMBERLOFF, D., 1996. Impacts of introduced species in the United States. Consequences, vol. 2, p. 13-24.

STEIDINGER, KA. and TANGER, K., 1997. Dinoflagellates. In TOMAS, CR. (Ed.). Identifying marine phytoplankton. San Diego: Academic Press. p. 387-584.. http://dx.doi.org/10.1016/ B978-012693018-4/50005-7.

TERROR, VL., SOUSA, HC. and KOZOVITS, AR., 2011. Produção, decomposição e qualidade nutricional da serapilheira foliar em uma floresta paludosa de altitude. Acta Botanica Brasilica, vol. 25 , no. 1 , p. 113-121.

VITOUSEK, PM., D’ANTONI, CM., LOOPE, LL. and WESTBROOKS, R., 1996. Biological invasions as a global environmental change. American Scientist, vol. 84, p. 468-478.

WHITTINGTON, J., SHERMAN, B., GREEN, D. and OLIVER, RL., 2000. Growth of Ceratium hirundinella in a subtropical Australian reservoir: the role of vertical migration. Journal of Plankton Research, vol. 22, no. 6, p. 1025-1045. http://dx.doi. org/10.1093/plankt/22.6.1025.

WHITTON, BA., JOHN, DM., KELLY, MG. and HAWORTH, EY., 2003. A coded list of freshwater algae of the British Isles. 2nd ed. London: Natural History Museum.

WILLIAMSON, M., 1996. Biological invasions. London: Chapmann and Hall. p. 243.

WU, JT. and CHOU, JW., 1998. Dinoflagellate associations in Feitsui Reservoir, Taiwan. Botanical Bulletin of Academia Sinica, vol. 39 , p. 137-145. 